\title{
Plasma binding capacity for 25-hydroxy-vitamin D in the elderly
}

\author{
W. J. MACLENNAN AND JUDITH C. HAMILTON \\ From South Laboratory and Pathology Block, Southampton General Hospital SO9 4XY, UK
}

SUMMARY Plasma 25-hydroxy-vitamin D (25-OHD) concentrations and 25-OHD binding capacities were measured in 14 elderly patients and in 14 young controls. Both 25-OHD concentrations and 25-OHD binding capacities were reduced in the elderly. In neither group, however, was there a significant correlation between 25-OHD binding capacities and 25-OHD concentrations. Thus, although 25-OHD binding capacities are reduced in sick old people this does not account for the low 25-OHD concentrations often found in this group.

Vitamin D deficiency is an important cause of sickness and disability in old age (Anderson et al., 1966; Chalmers et al., 1967). Investigation of this was given considerable impetus when methods were developed for measuring 25-hydroxy-vitamin D (25-OHD), the liver metabolite of ergocalciferol and cholecalciferol (Haddad and Chyu, 1971a; Belsey et al., 1974). Levels of the metabolite are low in elderly patients either resident in a long-stay unit or admitted to hospital from home (Corless et al., 1975; Nayal et al., 1978).

Though both dietary deficiency and lack of sunlight are major causes of low plasma 25-OHD concentrations in sick old people, other factors may be important. There is evidence, for example, that in old age the hydroxylation of ergocalciferol to 25$\mathrm{OHD}_{3}$ may be impaired (Rushton, 1978). A further, as yet unexplained, possibility is that low 25-OHD levels might be due to the effect of ill health on the 25-OHD binding capacity of plasma. Concentrations of many other carrier proteins are reduced in sick old people, and it is possible that 25-OHD binding protein levels might also be altered (Hodkinson, 1975). The present paper deals with an investigation of this hypothesis.

\section{Subjects}

Samples of blood in tubes containing heparin were collected from seven men and seven women aged 22 to 34 years. They were either members of staff or medical students. The same numbers of men and women were selected at random from patients

Received for publication 25 September 1978
Table Ages and principal diagnoses in patients admitted to geriatric unit

\begin{tabular}{lllll}
\hline Males & & \multicolumn{2}{l}{ Females } \\
\cline { 1 - 1 } Age & Principal diagnosis & & Age & Principal diagnosis \\
\hline 87 & Hemiparesis & 95 & Osteoarthritis of knees \\
81 & Alzheimer's disease & 80 & Osteoarthritis of knees \\
76 & Amputee & 79 & Urinary incontinence \\
71 & Parkinsonism & 76 & Pernicious anaemia \\
71 & Fractured shaft of femur & 78 & Quadriplegia \\
65 & Hemiparesis & 76 & Deep leg vein thrombosis \\
80 & Chronic bronchitis & 85 & Osteoarthritis of knees \\
\hline
\end{tabular}

admitted to a geriatric assessment unit. Their ages ranged from 66 to 95 years. The accompanying table lists their ages and principal diagnoses.

\section{Materials}

$\left({ }^{3} \mathrm{H}-26,27\right)$ 25-hydroxy-cholecalciferol (specific activity $9.4 \mathrm{Ci} / \mathrm{mmol}$ ) was purchased from the Radiochemical Centre, Amersham. Crystalline standard 25-hydroxy-cholecalciferol $\left(25-\mathrm{OHD}_{3}\right)$ was kindly supplied by Dr John Babcock of the Upjohn Company.

\section{Methods}

25-OHD ASSAY

Plasma 25-OHD levels were measured by a competitive protein-binding method which was essentially the same as that described by Belsey and his colleagues (1974).

\section{5-OHD BINDING CAPACITY}

The method used was that described by Haddad and 240 
his colleagues (1976) but there were some modifications. Plasma was diluted with barbital acetate buffer, $\mathrm{pH} 8.6$, to give incubations containing $0.5 \mu \mathrm{l}$ per tube. Increasing amounts of ${ }^{3} \mathrm{H} 25-\mathrm{OHD}_{3}$ in $50 \mu \mathrm{l}$ of ethanol were added to either $50 \mu \mathrm{l}$ ethanol or $0.5 \mu \mathrm{g}$ $25-\mathrm{OHD}_{3}$ in $50 \mu \mathrm{l}$ ethanol; $1.0 \mathrm{ml}$ of diluted plasma was then added and the resultant mixture was left at $0^{\circ} \mathrm{C}$ for one hour. Unbound sterol was removed using dextran-coated charcoal, and, after centrifugation, the supernatants were decanted into scintillation vials containing $10 \mathrm{ml}$ of fluid consisting of Triton $\mathrm{X}-100$ in toluene, $1: 2 \mathrm{v} / \mathrm{v}$, containing $0.03 \% 1$, 4-bis(5-phenyloxazol-2-yl) benzene and $0.5 \% 2,5$ diphenyloxazole.

Counting produced levels of radioactivity for serial amounts of ${ }^{3} \mathrm{H}$ 25-OHD mixed with diluted plasma, or diluted plasma in which 25-OHD specific binding protein had been saturated with added non radioactive $25-\mathrm{OHD}_{3}$ (Fig. 1). Subtraction of the latter from the former produced a graph of radioactivity attributable to ${ }^{3} \mathrm{H} 25-\mathrm{OHD}_{3}$ bound to $25-\mathrm{OHD}_{3}$ specific protein.

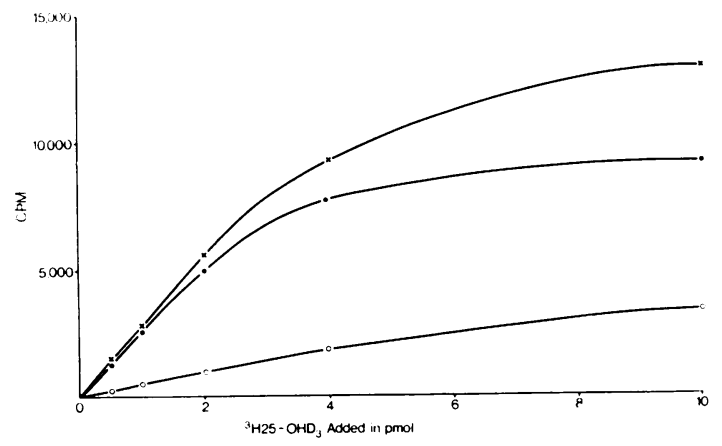

Fig. $1{ }^{3} \mathrm{H}-25-\mathrm{OHD}$, binding by plasma in a youny adult: $\times$ total supernatant radioactivity; $\bigcirc$ non specifically bound radioactivity; 1 calculated specifically bound radioactivity.

\section{Results}

25-OHD concentrations and 25-OHD binding capacities are expressed as nanomoles per litre. For conversion to nanograms per millilitre all results should be divided by $2 \cdot 5$. The means and standard deviations for 25-OHD binding capacity in healthy young adults and sick old people were $2560 \pm 350$ nmol/l and $2090 \pm 450 \mathrm{nmol} / \mathrm{l}$, respectively, giving a significantly lower value in the latter $(\mathrm{P}<0.001)$ (Fig. 2). There was also a striking difference in plasma 25-OHD concentrations in young and old where geometric means and $95 \%$ confidence limits were $52 \cdot 8(21 \cdot 0-132 \cdot 7) \mathrm{nmol} / \mathrm{l}$ and $9.6(1 \cdot 3-68 \cdot 7)$

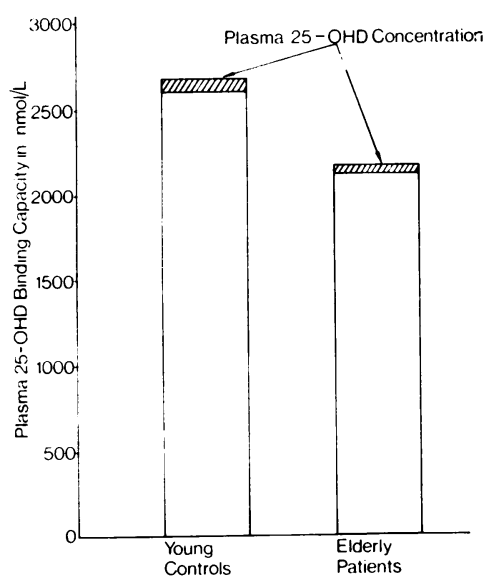

Fig. 2 Plasma 25-OHD concentrations and 25-OHD binding capacities in young controls and elderly patients.

nmol/1 respectively $(\mathrm{P}<0.001)$. Plasma 25-OHD concentrations were divided by 25-OHD binding capacity to give per cent $25-\mathrm{OHD}$ binding. This was significantly higher in youth than in old age, geometric means and $95 \%$ confidence limits being $2 \cdot 1$ $(0 \cdot 6-7 \cdot 6) \%$ and $0.6(0-3 \cdot 5) \%(\mathrm{P}<0.001)$ respectively. A negative correlation between 25-OHD binding capacity and plasma 25-OHD concentrations in young adults was not statistically significant $(r=$ $-0.392 ;$ P > 0.05) (Fig. 3). Again, in the elderly, a positive correlation between the two parameters was not statistically significant $(r=0.113 ; P>0.05)$.

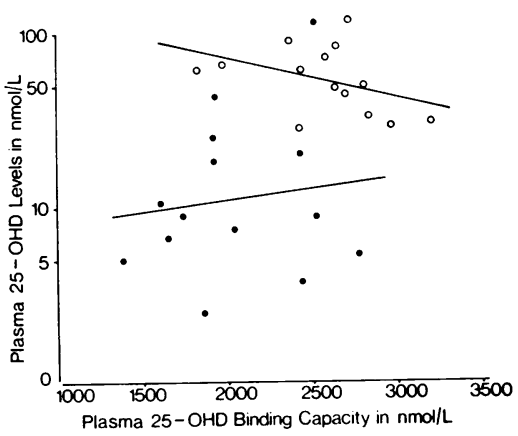

Fig. 3 Plasma 25-OHD levels and 25-OHD binding capacities in young controls $(\bigcirc)$ and elderly patients (O).

\section{Discussion}

Vitamin D binding protein (DBP) has $\alpha$-mobility on electrophoresis and has an estimated molecular 
weight of 52000 (Imawari and Goodman, 1977; Haddad and Chyu, 1971b). Daiger and colleagues (1975) have proposed that DBP is identical with the previously reported group-specific component (Gc) proteins. Though DBP has a higher affinity for 25 OHD than vitamin D it has a binding capacity for only one molecule of 25-OHD per molecule of the protein (Imawari et al., 1976). Concentrations of DBP vary in different clinical situations. They are elevated in pregnancy or during the administration of oestroprogesterones but reduced in cord blood or in hepatic cirrhosis (Bouillon et al., 1977a; Bouillon et al., 1977b).

In the present study, an indication of DBP concentrations was obtained by the simple measurement of the binding capacity of DBP for $25-\mathrm{OHD}_{3}$. The binding capacity of plasma from sick old people was lower than that measured in healthy young adults. The difference may be due to the effect of ill health on protein synthesis. Similar changes in serum albumin, transferrin, and thyroxine-binding globulin levels have been noted in elderly patients admitted to a geriatric unit (Hodkinson, 1975).

It should be noted that though none of the elderly subjects was suffering from disorders known to affect DBP all had illnesses sufficiently severe to lead to hospital admission. This group was studied because $25-\mathrm{OHD}_{3}$ deficiency is primarily a problem of old people who are also suffering from sickness and disability. Healthy old people have levels that are comparable with those of young adults (MacLennan and Hamilton, 1978).

The fact that both plasma 25-OHD concentrations and 25-OHD binding capacities were reduced in sick old people raises the possibility that the former might have been due to the latter. If this were the case, however, some relationship between individual 25OHD concentrations and 25-OHD binding capacities might be expected. The fact that no such correlation emerged suggests that the two parameters were not linked to each other and that the reduction in binding capacity was not sufficient to cause an alteration in plasma 25-OHD concentrations.

Our study has confirmed the conclusion of Imawari and Goodman (1977) that plasma 25-OHD concentrations and 25-OHD binding capacities are also independent of each other in young adults. The probable reason for the dissociation in both old and young subjects is that DBP has a large capacity for 25-OHD in comparison with the comparatively low 25-OHD concentrations normally present in plasma. Percentage saturations of the total 25-OHD binding capacity found in the present study are comparable with those found in a previous report where, in the absence of metabolic bone disease, values lay between 2 and $3 \%$ (Haddad et al., 1976). Such a major discrepancy between the metabolite and its transport protein means that DBP levels have an effect on metabolite concentrations only in exceptional circumstances. This may occur where pharmacological doses are given for prolonged periods of time (Haddad and Stamp, 1974). Even where there is evidence of vitamin $\mathbf{D}$ intoxication, however, plasma concentrations of 25-OHD rarely reach saturation point (Bouillon et al., 1977b).

The evidence then is that in sick old people there is a marginal reduction in the 25-OHD binding capacity of plasma but that this is not sufficient to account for the striking reductions in plasma 25-OHD concentrations which they often exhibit. Much larger numbers of subjects would be required to identify the specific diseases responsible for a reduced 25 OHD binding capacity or the relative effects of disease and ageing on this. Such an investigation, however, would be unlikely to alter our conclusion that the plasma 25-OHD binding capacity is rarely a major determinant of vitamin $\mathrm{D}$ status in old age.

\section{References}

Anderson, I., Campbell, A. E. R., Dunn, A., and Runciman, J. B. M. (1966). Osteomalacia in elderly women. Scottish Medical Journal, 11, 429-435.

Belsey, R. E., de Luca, H. F., and Potts, J. T., Jr. (1974). A rapid assay for $25-\mathrm{O}$ vitamin $\mathrm{D}_{3}$ without preparative chromatography. Journal of Clinical Endocrinology and Metabolism, 38, 1046-1051.

Bouillon, R., van Baelen, H., and de Moor, P. (1977a). 25-Hydroxyvitamin $\mathrm{D}$ and its binding protein in maternal and cord serum. Journal of Clinical Endocrinology and Metabolism, 45, 679-684.

Bouillon, R., van Baelen, H., and de Moor, P. (1977b). The measurement of the vitamin $\mathrm{D}$ binding protein in human serum. Journal of Clinical Endocrinology and Metabolism, 45, 225-231.

Chalmers, J., Conacher, W. D. H., Gardner, D. L., and Scott, P. J. (1967). Osteomalacia-a common disease in elderly women. Journal of Bone and Joint Surgery, 49B, 403-423.

Corless, D., Beer, M., Boucher, B. J., Gupta, S. P., and Cohen, R. D. (1975). Vitamin-D status in long-stay geriatric patients. Lancet, 1, 1404-1406.

Daiger, S. P., Schanfield, M. S., and Cavalli-Sforza, L. L. (1975). Group-specific component (Gc) proteins bind vitamin D and 25-hydroxy-vitamin D. Proceedings of the National Academy of Science of the United States of America, 72, 2076-2080.

Haddad, J. G., Jr., and Chyu, K. J. (1971a). Competitive protein-binding radioassay for 25-hydroxycholecalciferol. Journal of Clinical Endocrinology and Metabolism, 33, 992-995.

Haddad, J. G., Jr., and Chyu, K. J. (1971b). 25-Hydroxycholecalciferol-binding globulin in human plasma. Biochimica et Biophysica Acta, 248, 471-481. 
Haddad, J. G., Jr., Hillman, L., and Rojanastahit, S. (1976). Human serum binding capacity and affinity for 25-hydroxyergocalciferol and 25-hydroxy-cholecalciferol. Journal of Clinical Endocrinology and Metabolism, 43, 86-91.

Haddad, J. G., Jr., and Stamp, T. C. B. (1974). Circulating 25-hydroxyvitamin D in man. American Journal of Medicine, 57, 57-62.

Hodkinson, H. M. (1975). Diagnostic and prognostic aspects of routine laboratory screening of the geriatric in-patient. DM thesis, University of Oxford.

Imawari, M., and Goodman, D. S. (1977). Immunological and immunoassay studies of the binding protein for vitamin D and its metabolites in human serum. Journal of Clinical Investigation, 59, 432-442.

Imawari, M., Kida, K., and Goodman, D. S. (1976). The transport of vitamin D and its 25-hydroxy metabolite in human plasma. Journal of Clinical Investigation, 58, 514-523.

MacLennan, W. J., and Hamilton, J. C. (1978). Low plasma-25-hydroxy-vitamin D without osteomalacia (Letter). Lancet, 1, 1210.

Nayal, A. S., MacLennan, W. J., Hamilton, J. C., Rose, P., and Kong, M. (1978). 25-Hydroxy-vitamin D, diet and sunlight exposure in patients admitted to a geriatric unit. Gerontology, 24, 117-122.

Rushton, C. (1978). Vitamin D hydroxylation in youth and old age. Age and Ageing, 7, 91-95.

Requests for reprints to: Dr W. J. MacLennan, Centre Block (E.620), Southampton General Hospital, Tremona Road, Southampton SO9 4XY, UK 